Article

\title{
Living Dendrolitic Microbial Mats in Hamelin Pool, Shark Bay, Western Australia
}

\author{
Erica P. Suosaari ${ }^{1,2, *}$, Stanley M. Awramik ${ }^{3}$, R. Pamela Reid ${ }^{4}$, John F. Stolz ${ }^{5}$ and Kathleen Grey ${ }^{6}$ \\ 1 Department of Mineral Sciences, National Museum of Natural History, Smithsonian Institution, \\ Washington, DC 20560, USA \\ 2 Bush Heritage Australia, Melbourne, VIC 3000, Australia \\ 3 Department of Earth Science, University of California, Santa Barbara, CA 93106, USA; awramik@geol.ucsb.edu \\ 4 Rosenstiel School of Marine and Atmospheric Science, University of Miami, Miami, FL 33149, USA; \\ preid@rsmas.miami.edu \\ 5 Department of Biological Sciences, Duquesne University, Pittsburgh, PA 15282, USA; stolz@duq.edu \\ 6 Department of Mines, Industrial Regulations and Safety, Geological Survey of Western Australia, \\ East Perth, WA 6076, Australia; kath.grey@gmail.com \\ * Correspondence: erica.suosaari@bushheritage.org.au; Tel.: +1-703-403-3207
}

Received: 24 April 2018; Accepted: 5 June 2018; Published: 11 June 2018

\begin{abstract}
Hamelin Pool, Shark Bay, Western Australia, is home to the largest and most diverse assemblage of living marine stromatolites, with shapes and sizes comparable to ancient structures. A recent field-intensive program revealed seasonally ephemeral occurrences of modern dendrolitic microbial mats forming in intertidal, low energy settings. Dominated by filamentous cyanobacteria, dendrolitic microbial mats are formed when filaments provide a supporting framework as a result of gliding mobility, to build a shrubby morphology. Dendrolites, known throughout the rock record, refer to macroscopic microbialites with mesostuctures composed of unlaminated arborescent structures called shrubs. In these modern examples, thick filaments of Lyngbya aestuarii form the "trunk" of the bush, with finer filaments of Lyngbya fragilis, Phormidium sp. and Schizothrix sp. forming the "branches" These biologically-influenced dendrolitic structures provide insight into the complex interplay of microbial communities and the environment, broadening our understanding of shrub and dendrolite formation throughout the rock record.
\end{abstract}

Keywords: dendrolite; shrubs; microbialites; Hamelin Pool; non-lithifying microbial mats; Lyngbya; cyanobacteria

\section{Introduction}

Complex life, complete with hard parts that could be fossilized and preserved in the rock record, did not appear until relatively late in the earth's history. The fossilization of organisms within the rock record before the evolution of these skeletonized, complex organisms was rare, occurring only in environments with specific sedimentary conditions conducive to preservation [1]. Prior to the radiation of this higher, more complex life, the fossil record consists largely of three types of fossils: permineralized microfossils in chert, organic-walled microfossils preserved in siliciclastic rocks, and microbialites in limestone and dolostone. Burne and Moore [2] defined microbialites as "organosedimentary deposits that have accreted as a result of a benthic microbial community trapping and binding detrital sediment and/or forming the locus of mineral precipitation". Microbialites span over $80 \%$ of the earth's history [3].

Although topographic relief is the distinguishing characteristic of most microbialites, the complex interplay of biological versus environmental (e.g., physical and chemical) factors has resulted in many questions surrounding the genesis of particular structures [4-10]. Despite over 100 years of 
research, specific processes that control the morphology of many microbialite structures remain enigmatic [7,11]. Moreover, physical, chemical and biological processes influencing microbialite morphogenesis may be scale-dependent [12], further complicating the disentanglement of responsible growth variables. Environmental pressures are typically credited with driving morphology at the macroscale, whereas microscale features are attributed to biology [5,13], whereby small scale, localized controls affect the highly variable morphologies between adjacent microbialite structures [12]. As a result, interpreting the deposition environment versus the biological contribution of microbialites throughout the fossil record can be challenging. Few cases have been documented where the microbiota influenced microbialite shape (e.g., Awramik and Semikhatov [14]), with the result that many researchers question direct microbial control of the microbialite macrostructure [11,15-19]. This does not necessarily mean that physical and chemical factors have the overwhelming control. It could mean we have yet to effectively disentangle all the variables.

Studies in modern microbial environments can help to interpret processes driving microbialite morphologies in the rock record because living structures can be documented over observable time-scales [12]. In particular, the role of biological influence on morphology can be examined. Despite the skepticism of some authors, some morphologies do suggest strong correlations between biological behavior and the form and structure of microbialites. Examples include reticulate and cuspate morphologies and pinnacle/tufted morphologies, where filamentous bacteria glide and tangle with each other [10,20-22], and pustular morphologies, where individual pustules reflect the cell division processes in coccoid bacteria [23]. Additionally, bacteria are capable of communicating within a community to form complex colonies that are able to organize in a way best suited to specific environmental pressures [24]. These dynamic interactions between microbial communities coupled with environmental conditions result in diverse structural morphologies [12,25,26].

In some cases, microbial structures share similar morphologies with non-microbially-mediated structures (dubiomicrobialites and pseudomicrobialites, after Hofmann [27]); understanding microbialite morphology is therefore critical in order to recognize biogenicity in the fossil record [28]. Characteristic microbialite mesostructures are divided into the following broad divisions: leiolite (aphanitic), stromatolite (laminated), thrombolite (clotted), and dendrolite (dendritric) [3,29,30]. Moreover, certain morphologies may reflect particular microbial communities [4], serving as the basis for taxonomic description and providing insight into possible functional behaviors. Indeed, morphology-based similarities have long been used for the biostratigraphic correlation of strata [31,32] with considerable success [33-36]. Morphologies can also reveal potential relationships that can help determine environmental controls on microbialite-building biological communities [37]. Subsequently, the identification of similar microbialite morphologies from vastly different environments may indicate that a specific morphology is biologically controlled [4].

Establishing a living counterpart that is analogous to a fossil helps to better understand the biogenic nature of that fossil [28]. This practice is well-established for microbialites, such as living stromatolites and thrombolites, which are well-known and described in many locations across the globe [2,38-44]. This is not the case for dendrolites. In the rock record, dendrolites occur as domes or small columns, biostromes, and as rinds on other microbialites [45]. Dendrolites became widespread in the early Cambrian and are best known from the Cambrian to the early Ordovician, late Devonian and Early Triassic [3,46]. Extant potential homologs of dendrolites are rare.

In addition to a paucity of modern analogs, understanding living and fossil dendrolites has been hampered by semantic issues. The term "dendrolite" was introduced by Riding in 1988 [30] for fossilized "biomineralized microbial deposits with a dominant dendritic macrofabric". Later, he added that dendrolites were "typically produced by calcified microbes" [30] (p. 194). The presence of calcimicrobes was used by Shapiro and Rigby [47] to differentiate dendrolites from other microbialites in their Cambrian rocks. The term has also been used for the individual dendritic structure with laminated and peloidal microstructures [46]. Although there has been much emphasis on the presence of calcimicrobes, it is still unclear whether these are a mandatory, and therefore a diagnostic characteristic of a dendrolite, and as reported here, other organisms may be significant in forming shrub-like structures. Inconsistencies in usage can be 
minimized by considering the following: dendrolites are one of four major types of microbialites that are recognized by their characteristic mesostructured, namely stromatolite (laminated), thrombolite (clotted), dendrolite (dendritic), and leiolite (aphanitic) [30]. Thus, dendrolite refers to a macroscopic microbialite that has a mesostructure composed of unlaminated arborescent structures called shrubs [48]. If these mesoscopic structures are laminated, as described in Ibarra et al. [46], they should properly be called ministromatolites. We use shrub and dendrolitic structure interchangeably in this paper.

There are various interpretations regarding the origin of arborescent branching in ancient dendrolites. For instance, shrubs between tube structures in tuberock from the Neoproterozoic are postulated to be composed of calcimicrobes [49,50]. Cambro-Ordovician dendrolites are interpreted to have been constructed by elongate, vertically-oriented, narrow clusters of calcified microbes [37,47]. An overall review of dendrolites through geological time is required to resolve some of the inconsistencies, and the examination of living examples will play a vital role in such analysis.

However, only a few extant potential homologs of dendrolites and shrubs have been described. Shrubs were reported from hot-water travertine deposits [51,52]. Folk, Chafetz and other authors attribute some of these shrubs to bacterial activity, but suggest that the shrub morphology is controlled primarily by crystal growth. The term "dendrolite" was rarely used when describing these travertine deposits [53]. Dendrolitic branching cones, which could be called shrubs, were recently described in a geothermal pool [54]. Detailed microbiological characterization of these structures supported the authors' hypothesis that biological activity may be a controlling factor in their formation. These travertine examples are from thermal waters.

To date, we are unaware of any previous reports of extant shrubs forming in marine or lacustrine settings, yet the fossil record has many examples from these two environments. Here, we present findings of the first known occurrence of living shrubs forming as a result of microbial activity in a marine environment in Hamelin Pool, Shark Bay, Western Australia (Figure 1). Hamelin Pool has been a kind of Rosetta Stone for stromatolites. The first known modern stromatolites with sizes and shapes equivalent to Precambrian forms were discovered there in the 1950s, and have formed the primary basis for comparison with fossil examples [55]. With an area covering around $1400 \mathrm{~km}^{2}$ and a $135 \mathrm{~km}$ shoreline dominated by microbial mats and structures [26], the Hamelin Pool microbial system is an ideal living laboratory in which to observe living examples of shrubs that could ultimately form dendrolites.

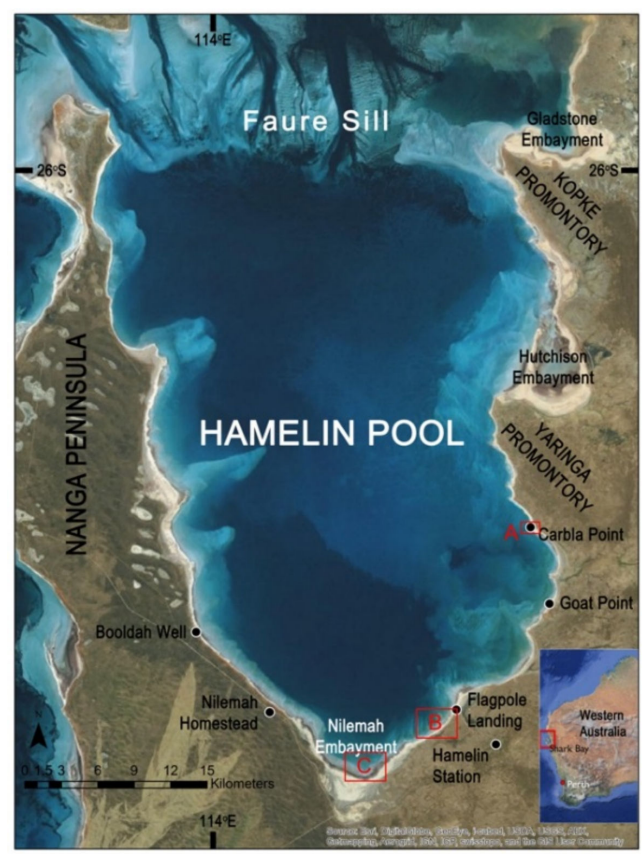

Figure 1. Location map. Map showing the location of Hamelin Pool and key localities around the margin. Base map and inset source: Esri, DigitalGlobe, Earthstar Geographics, CNES/Airbus DS, GeoEye, USDA FSA, USGS, Aerogrid, IGN, IGP, and the GIS User Community. 


\section{Materials and Methods}

\subsection{Location}

Hamelin Pool (Figure 1) is a shallow embayment with unusual environmental parameters located within the double-bay inlet system of Shark Bay, on Western Australia's coastline about $800 \mathrm{~km}$ north of Perth. Metahaline water [56] (37-43\%) floods through channels in the Faure Sill, a carbonate sand and sea grass bank that largely bars Hamelin Pool from the rest of Shark Bay. Limited flushing of water through the sill, low rainfall and high evaporation result in hypersaline conditions. The maximum depth of Hamelin Pool is $11 \mathrm{~m}$, resulting in a substantial annual temperature range (spanning $22{ }^{\circ} \mathrm{C}$ at $2 \mathrm{~m}$ water depth [57]) and a nearly two-meter annual change in water level, with higher highs and lows leaving parts of the margin largely submerged in the Austral autumn months, and lower highs and lows exposing more of the margin during the Austral spring months [55,57,58]. Hamelin Pool's unique environmental conditions restrict predators $[26,38,55,58]$, thereby supporting the growth and accretion of microbialite-building bacterial communities.

\subsection{Field Studies, Sampling, and Analysis}

Field-intensive studies were conducted in Hamelin Pool during March and April 2012, 2013 and 2014, with additional site visits in November 2013 and 2014. Detailed observations of bottom types were made around the entirety of the margins of Hamelin Pool. Shrubs were found in several localities, and were sampled and processed as follows.

Shrub samples were collected and maintained in unfiltered Hamelin Pool water for light and fluorescence microscopy carried out in the field laboratory. Preserved samples were prepared at the time of collection in the field with the addition of either $2.5 \%$ glutaraldehyde or $4 \%$ formalin (both prepared in filtered full-strength Hamelin Pool water) and kept chilled and in the dark. Light micrographs were taken on an Olympus BX51 fluorescence microscope with a Micropublisher Camera (Q Imaging, Surry, BC, USA) [59]. Confocal scanning microscopy was carried out on fixed samples at Duquesne University, using two different systems. The first was a Leica TCS SP2 microscope (Leica Microsystems Inc., Mannheim, PA, USA) with the $488 \mathrm{~nm}$ laser used for excitation and the red channel (509-621 nm) for emissions [59,60]. The second confocal system was a Nikon A1R LUNV Confocal Imaging System (Nikon Instruments Inc., Melville, NY, USA) with the 488, 561, and $640 \mathrm{~nm}$ solid state lasers used for excitation and the TRITC, FITC, and CYAN presets for emissions (green, red, and fuchsia channels, respectively). Preserved samples were further characterized using high resolution microscopy. Samples for transmission electron microscopy (TEM) were prepared as described in Stolz et al. [61] and Stolz et al. [59] and observed on a JEOL 1210 TEM (JEOL USA Inc., Peabody, MA, USA) at $60 \mathrm{kV}$. Samples for scanning electron microscopy (SEM) were dehydrated in an ethanol series (50\%, 70\%, 90\%, 95\%, 100\%) and dried with HMDS, mounted on aluminum studs with carbon film tape (Electron Microscopy Sciences, Hatfield, PA, USA) and observed on a Hitachi S3400N SEM (Hitachi High Technologies Inc., Schaumberg, IL, USA) at $2 \mathrm{kV}$. Although a metagenomic study of the shrubs would provide data on the total diversity of the shrubs and the mat, something we could follow up on, we focused on what we interpret to be the main constructors of the shrubs, which were visible using light, fluorescence and confocal scanning microscopy. These techniques have successfully been applied on Bahamian microbialites [59,60,62,63].

Additional subsamples of shrubs were impregnated with wax. Vertical strips were shaved using a scalpel. The shaving was oriented onto a glass slide and additional wax was added to embed the sliver onto the slide. The wax was semi-transparent, allowing overhead light to be used to examine the dendrolitic structures under a petrographic microscope. 


\section{Results}

\subsection{Distribution}

Living shrubs (a potential component of a dendrolite) (Figure 2) were discovered during March 2012 in the shallow subtidal zone in several locations at the south end of Hamelin Pool (Nilemah Embayment) (Figure 3). Upon returning to the sites in March 2013 and 2014, dendrolitic structures were not present at these locations, but were present in other locations not identified in 2012, including sites in Nilemah Embayment and at Goat Point (Figure 3). Dendrolitic structures were not observed during November field campaigns.

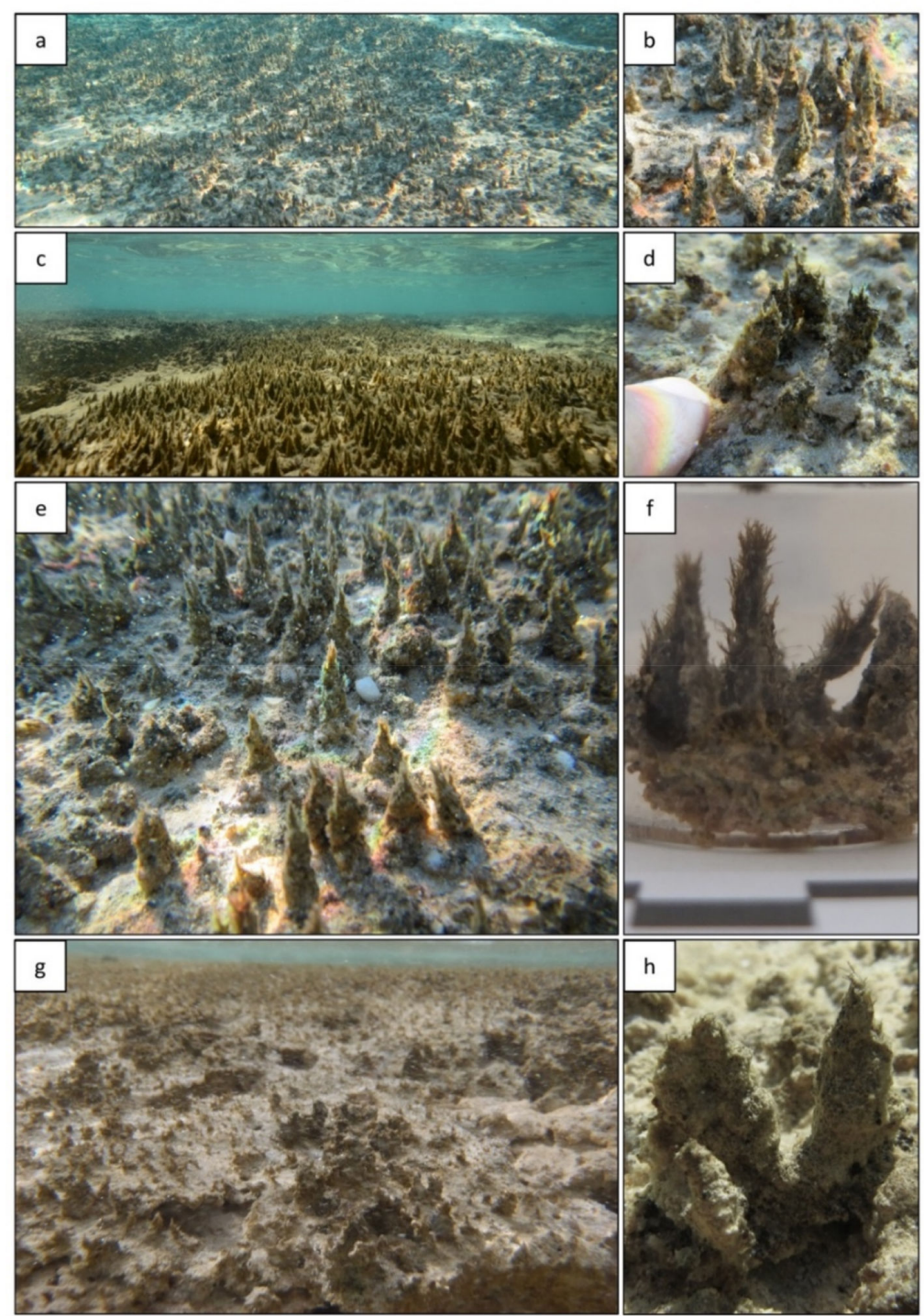

Figure 2. Images of living dendrolites in Hamelin Pool. (a) Living dendrolitic shrubs identified in 2012 from the west side of Nilemah Embayment (see Figure 3c-1). (b) Individual dendrolitic shrubs 1-2 cm in relief; detailed image from (a). (c) Living dendrolitic shrubs identified in 2013 from the east side of Nilemah Embayment (see Figure 3c-6). (d) Individual dendrolitic shrubs 1-2 cm in relief; detailed image from (c). (e) Living dendrolitic shrubs identified in 2013 from the western margin of Hamelin Pool, near the Playford transect (see Figure 3b-4). (f) Individual dendrolitic shrubs $2-3 \mathrm{~cm}$ in relief; detailed image from (e). (g). Living dendrolitic shrubs identified in 2013 from the western margin of Hamelin Pool (see northern yellow marker in Figure 3b-3). (h) Individual dendrolitic shrubs $\sim 1 \mathrm{~cm}$ in relief; detailed image from g). 
Hamelin Pool shrubs are found in the form of irregularly spaced branching structures, composed of small clumps of cyanobacteria with entangled sediment grains, forming on the flat underlying microbial mat surface (Figure 2). These structures are found in the mid to lower intertidal zone, colonizing microbialite surfaces and forming meter-scale fields of dendrolitic structures up to $3 \mathrm{~cm}$ high.
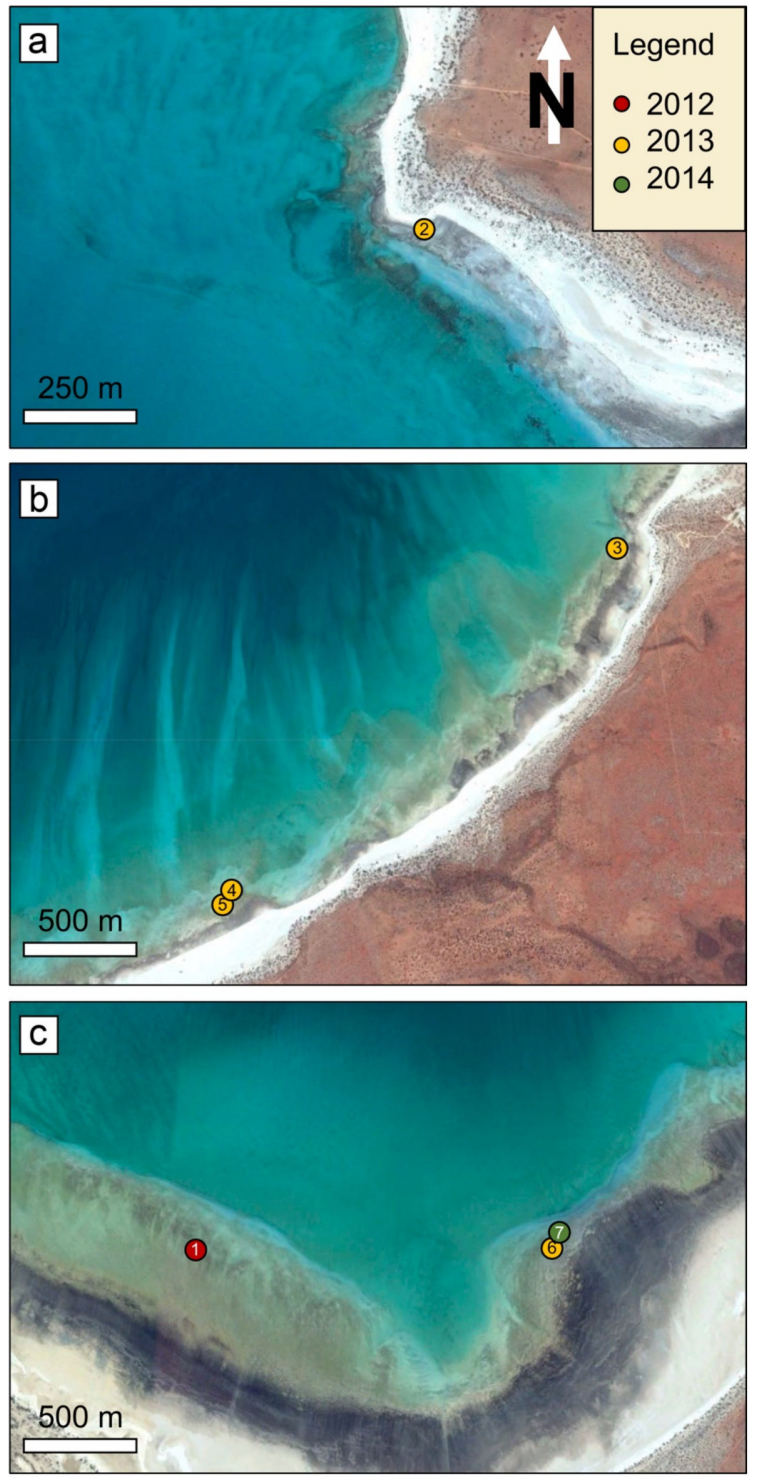

Figure 3. Locations of dendrolitic mats in Hamelin Pool examined between 2012 and 2014. See Figure 1 for locations within Hamelin Pool.

\subsection{Morphology and Microbial Composition}

Observations of wax impregnations showed that the dendrolitic structures lack laminae and an axial zone and in plan view and are elongated or blade-like (Figure 4), which distinguishes them from tufted and pinnacle mats. The structures display a thick cyanobacterial "trunk" coupled with radiating filaments of thinner cyanobacteria in a bushy/tree-like morphology. The margins are rough, with irregular morphology, and the thinner marginal branches entrap sediments. The cyanobacterial filaments are dark in color, resulting in light to dark-brown shrubs, with visibly lighter grains trapped amongst the finer filaments. Although rich in grains, Hamelin Pool shrubs are ephemeral and lack obvious carbonate precipitate and have not been observed to lithify. 


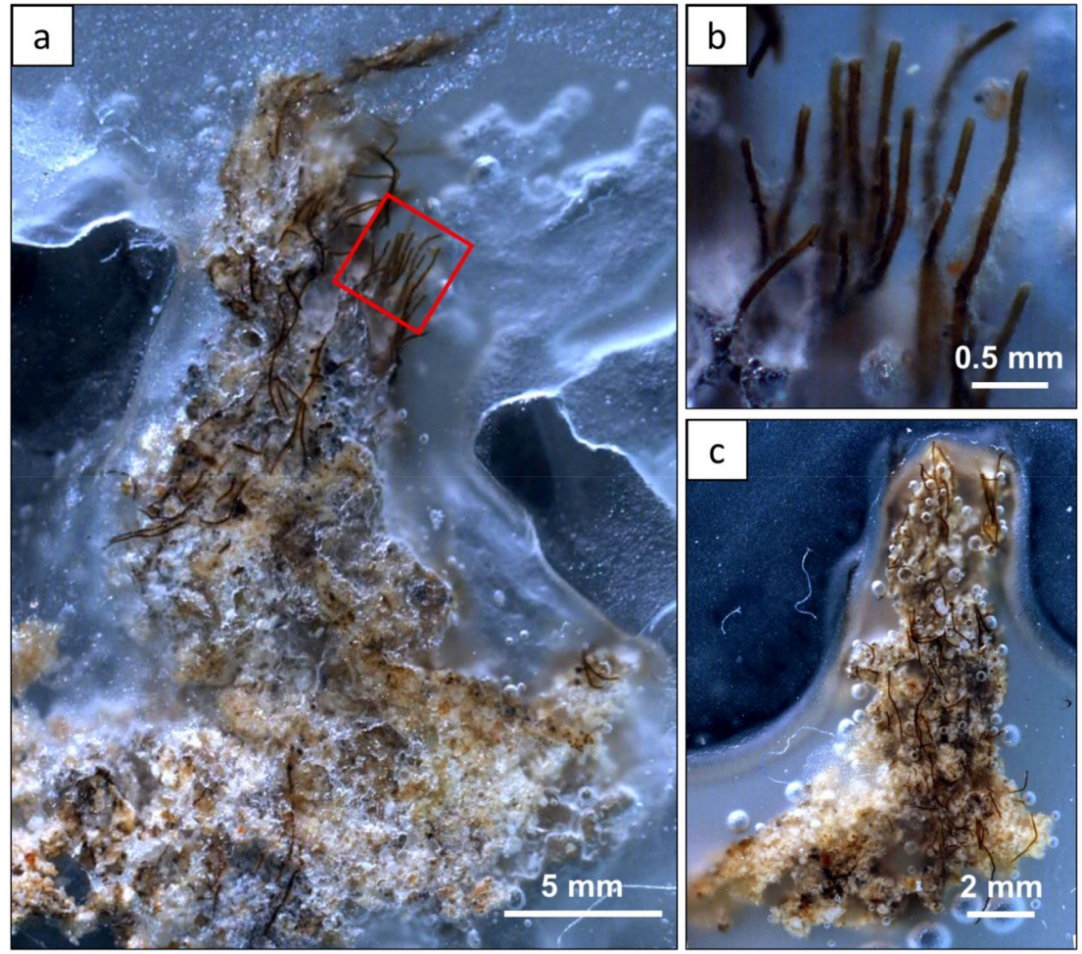

Figure 4. Petrographic photomicrographs of Hamelin Pool dendrolitic shrubs impregnated with wax, and embedded onto a thin section. Lyngbya aestuarii forms the "trunk" of the bush, with finer filaments of Lyngbya fragilis, Phormidium sp. and Schizothrix sp. forming the "branches". Sediments are also present throughout the shrub, however, as the wax is not transparent, the images were photographed using an overhead light, making sediments difficult to discern from wax in the image. (a) Photomicrograph showing a dendrolitic shrub. (b) Higher resolution image of finer filaments taken from (a), in the red box. (c) Photomicrograph showing a dendrolitic shrub.

The identification of the shrub-building cyanobacteria was based on morphologically distinct characteristics (e.g., filament width, cell dimensions, and sheath) using the descriptions of the major mat-building species at Shark Bay from previous publications $[38,64]$. Although molecular analysis could further solidify the identification of the cyanobacteria, the existing database for Shark Bay species is still limited and has not yet been cross-referenced with the morphological characteristics (i.e., specific morphotypes linked to specific 16s rRNA gene sequences) [65-69]. Moreover, our goal here was to focus on the microbe-mineral interaction (i.e., modularity) and whether these structures had fossil analogs.

Microscopy revealed that the distal end of each shrub shows a single large Lyngbya aestuarii filament at the center, barely exposed at the tip (Figure 5a). The trichomes of L. aestuarii are $22 \mu \mathrm{m}$ in diameter and surrounded by a darkly-pigmented sheath for a final thickness of up to $40 \mu \mathrm{m}$. They comprise the main central filament, with filaments of the thinner Lyngbya fragilis often wrapping around the central L. aestuarii filament (Figure 5b). The trichomes of L. fragilis are $10 \mu \mathrm{m}$ in diameter and are also surrounded by a densely pigmented sheath to a final thickness of $30 \mu \mathrm{m}$ (Figure $5 \mathrm{~b}$ ). Many shrubs have paired filaments of L. aestuarii, that diverge and are filled in between with sheath, other filamentous cyanobacteria such as L. fragilis, in addition to Schizothrix sp. (Figure 5b3,c), Phormidium sp. (Figure 5c), and Johannesbaptista sp. (Figure 6) as well as diatoms (Figure 7b). The cells comprising the trichomes of the latter three cyanobacteria (e.g., Phormidium, Schizothrix, Johannesbaptista) were morphologically distinct and had different widths $(1,2$, and $4 \mu \mathrm{m}$ respectively, Figures $5 \mathrm{c}$ and 6 ). Examination of a shrub tip by SEM revealed only a mass of extracellular matrix (e.g., extracellular polymeric substances (EPS)), filaments of L. fragilis and Schizothrix sp., and other 
smaller bacteria (Figure 7a). TEM revealed cross-sections of the thick sheath (e.g., EPS) produced by the filamentous cyanobacteria (e.g., Schizothrix sp., Phormidium sp., Figure 7c). Scanning confocal microscopy additionally revealed a diverse population of diatoms and coccoid cyanobacteria in addition to the major cyanobacterial species described above (Figure $8 \mathrm{a}-\mathrm{c}$ ). It was evident that the tips of the shrubs were free of sediment, comprised of cells and EPS (Figure 8a,b). The shrubs appear to grow out of a flat laminated mat that is comprised primarily of Schizothrix sp., Phormidium sp., and Johannesbaptista sp. (Figure 2h).

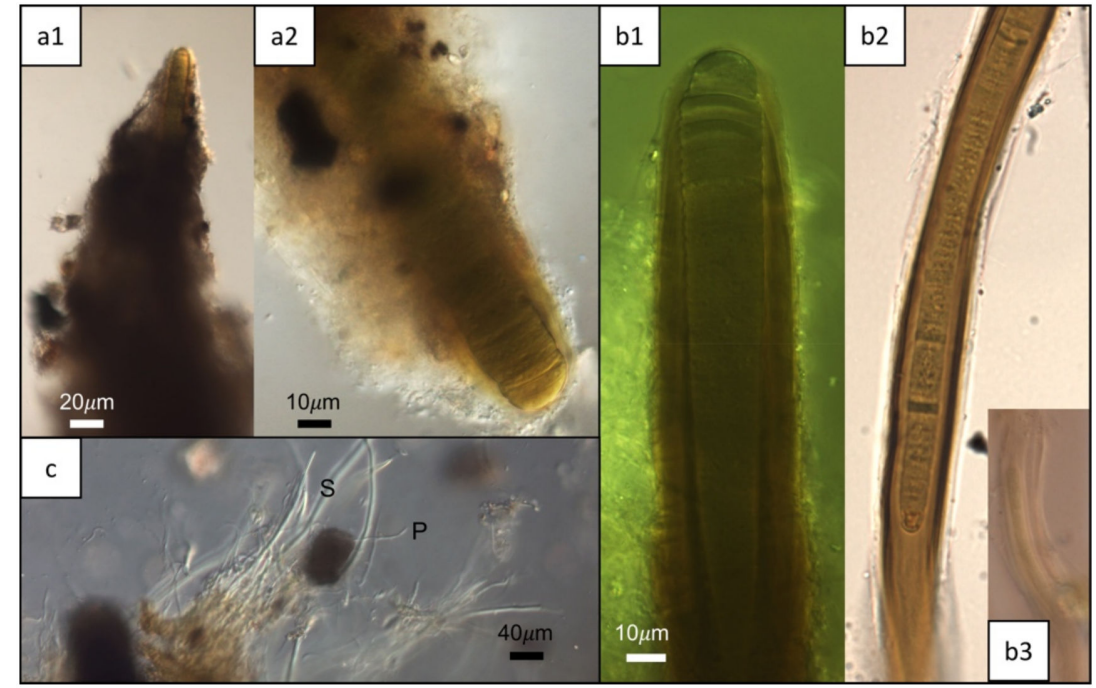

Figure 5. Cyanobacteria of the dendrolite, (a) Lynbya aestuarii, (a1) distal end of a shrub showing the exposed trichome tip of L. aestuarii under bright field; (a2) higher magnification of the tip of a filament of $L$ aestuarii, under differential interference contrast (differential interference contrast (DIC)). (b) Lyngbya fragilis, (b1) filament of L. fragilis under DIC showing thick sheath, (b2) filament of L. fragilis under bright field revealing the darkly pigmented sheath, (b3) filament of L. fragilis under DIC showing layers of sheath. (c) Filaments of Schizothrix sp. (S) and Phormidium sp. (P) under DIC.

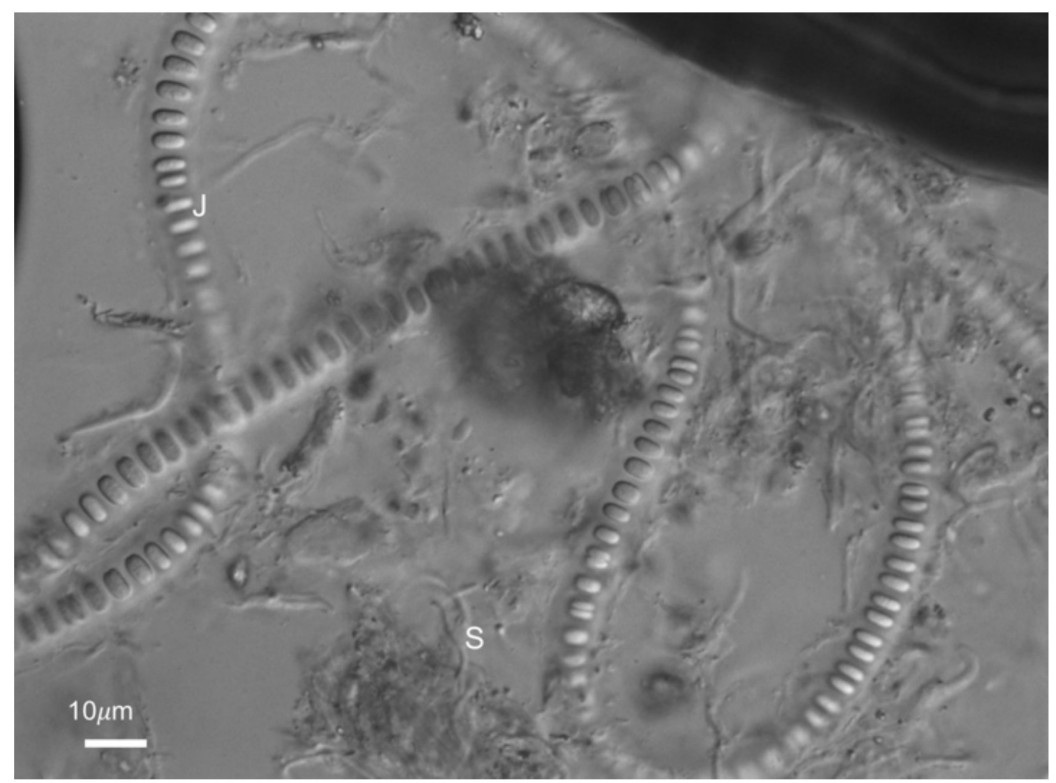

Figure 6. Filaments of Johannesbaptista sp. (J) and Schizothrix sp.(S), under DIC. 

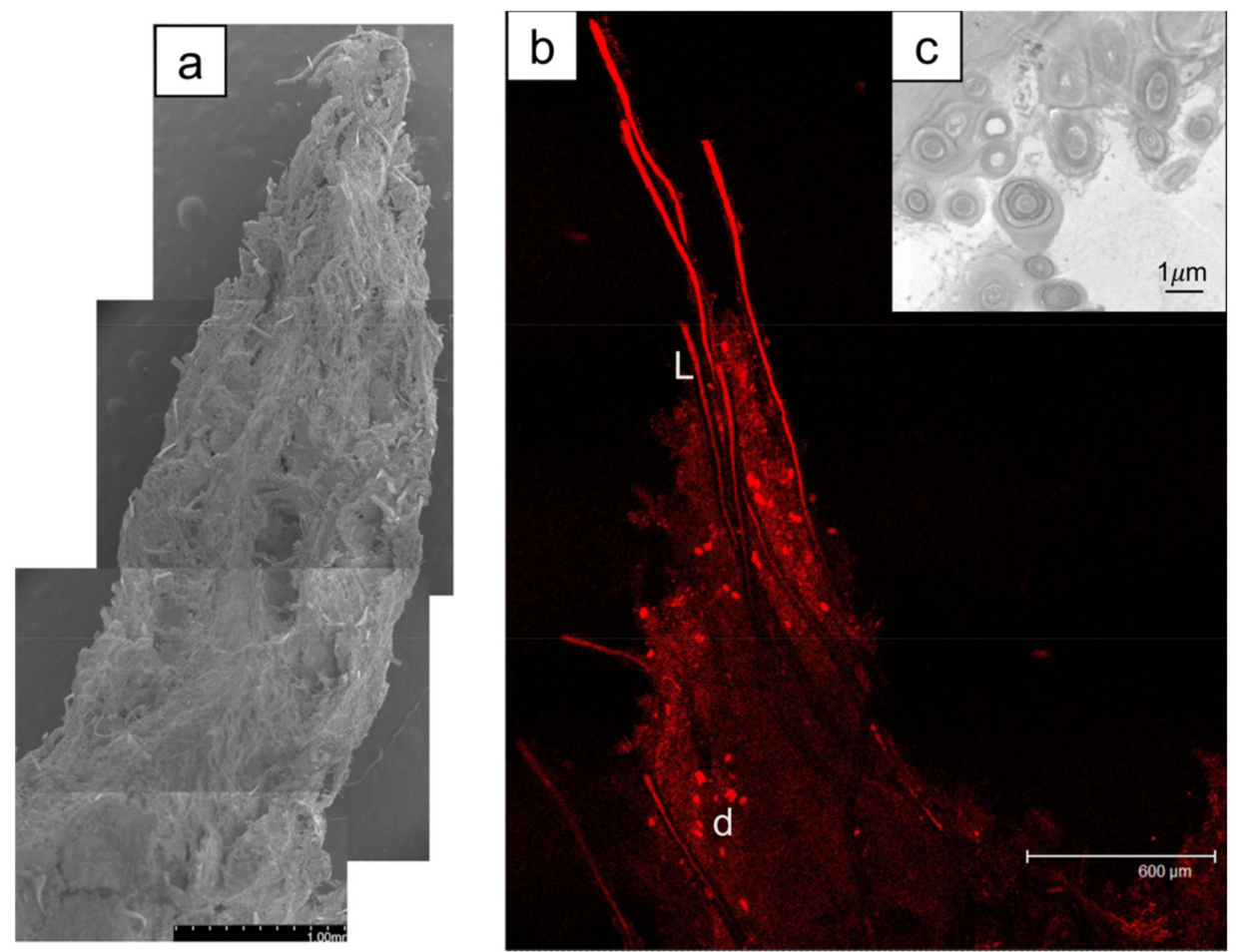

Figure 7. (a) SEM of a shrub tip covered with a sheath and attached microbes (scale $1 \mathrm{~mm}$ ). (b) Confocal scanning microscopy image (Leica TCS SP2) revealing a chlorophyll-containing species including L. aestuarii (L), diatoms (d) and sheath. Scale bar is $600 \mu \mathrm{m}$. (c) TEM of Schizothrix sp. (2 $\mu \mathrm{m}$ in diameter) and Phormidium sp. (1 $\mu \mathrm{m}$ in diameter) in cross-section. Scale bar $1 \mu \mathrm{m}$.
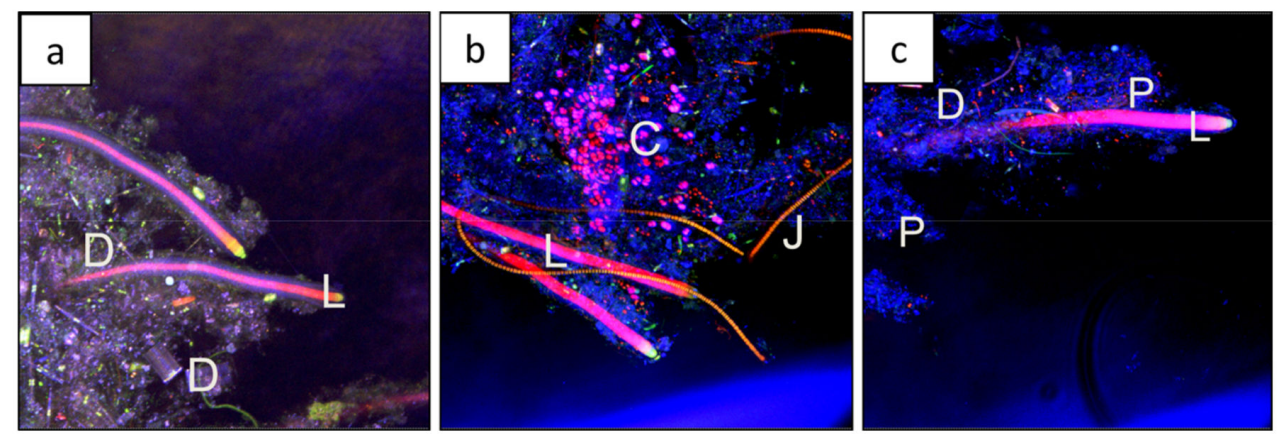

Figure 8. Scanning confocal microscopy (Nikon A1R LUNV) using both the autofluorescence to show chlorophyll-containing organisms, and reflectance to visualize sheath and precipitate. (a) Filaments of L. aestuarii (L) surrounded by extracellular polymeric substances (EPS) and diatoms (D); (b) Filaments of L. aestuarii (L) surrounded by EPS, coccoid cyanobacteria (C), filaments of Johannesbaptista sp. (J); (c) Filaments of L. aestuarii (L) surrounded by EPS and revealed diatoms (D), and precipitates (P).

\section{Discussion}

\subsection{Shrub Formation and Comparison to Pinnacle and Tufted Microbial Mats}

The ephemeral nature of shrub growth in Hamelin Pool, both with regard to location and seasonality, may reflect fluctuating environmental pressures. Shrub growth may therefore be controlled by seasonal variations, including changing water levels, the influx of nutrient-rich or alkaline ground water, water temperature, salinity and other chemical parameters. The average water temperature during March and April is approximately $25{ }^{\circ} \mathrm{C}$. Additionally, the average salinity recorded for March and August is between 65 and $70 \mathrm{psu}$ [57]. The average pH value recorded in the pool 
for March and April was 8.1 [70]. Long-term monitoring is needed to couple the appearance and disappearance of shrubs with specific environmental parameters. Microscopic examination has shown Hamelin Pool shrubs, which are composed of filamentous cyanobacteria, formed when the filaments built a bushy, tree-like morphology. Each dendrolitic structure is anchored by L. aestuarii, which forms the "trunk" of the shrub with finer filaments, including L. fragilis, Phormidium sp., and Schizothrix sp. forming the "branches" (Figure 4). The "branches" are rich in sediment grains. The microorganisms appear to act like a central reinforcing rod that supports a surrounding cylinder of sediment and EPS. This distinctive morphology and branching habit in these living analogues acts as a proxy to fossil counterparts, indicating that shrubs are primary features of biogenic origin.

Microbial mat morphologies are often attributed, but not limited to chemotaxis, phototaxis (optimization and avoidance strategies) [20,71-73], aerotaxis [74], competition for space and/or resources [75], nutrient diffusion [76], quorum sensing [77], periodic desiccation [39], and cooperative movement within the community to overcome burial [74]. The gliding mobility of filamentous cyanobacteria is well documented [10,20,21,78]. Similar to previously described pinnacle and tufted microbial mats, the dendrolitic morphology of Hamelin Pool shrubs can be largely attributed to the mobile gliding ability of the microbes.

In contrast to the pinnacle and tufted microbial mat morphologies, which are predominantly sediment poor, Hamelin Pool shrubs are enriched in grains. Filamentous cyanobacteria are better adapted than coccoid cyanobacteria in areas with higher sedimentation rates [7]. Sedimentation may impact growth and accretion by inducing the microbes to diverge and separate as a phototactic response that allows them to access light more efficiently [4]. However, Petroff et al. [76] suggests that the upward mobility of filamentous cyanobacteria is more likely in response to a diffusion-limited gradient in local nutrients or chemical profiles. The fluctuating seasonal environmental parameters in Hamelin Pool (i.e., salinity, temperature, water level, ground water influx [57] may influence the ephemeral nature of the shrub-building microbial communities. As such, elevated salinity levels may lead to an increase in EPS production [79], critical in the formation of dendritic branching morphologies [24]. Other environments hosting living microbial mats with pinnacle or tufted morphologies are typically in warm waters e.g., [20,80,81], a possible explanation for our finding dendrolitic morphologies only during the warmer, late summer months of the field campaigns. In times of stress and reduced nutrients, shrub morphology may be attributed to competition between microbes, or may be the result of a collaborative effort to improve access to nutrients and remain within optimal growth conditions [76,78,82].

The living dendrolitic structures discovered in Hamelin Pool (Figure 9a) are different from previously described tufted mats from the same area [21] (no vertical profile available), from the Little Hot Creek geothermal spring in California [54] (Figure 9b), from pinnacle mats in Yellowstone Park hot springs by Walter et al. [20] (Figure 9c), and in other geothermal areas, such as Ohaaki Pool and Kirihoro hot pool, New Zealand [80] ([83], Figure 11a), and in a solar pond ("Pamelup Pond", Lake Preston, Western Australia) ([84], Figure 19a); [85] (Figure 9d), as discussed below.

Dendrolitic cones in geothermal hot springs of California, suggested as a modern analog for dendrolites in [54], were described as having "mm-scale protrusions upon them, creating an arborescent appearance" ([54], Figure 1d). They commonly lacked laminations or other internal structures ([54], Figure 3a) (Figure 9b). Composed of interlocking filaments, the main tuft-constructing organisms were Phormidium, Leptolyngbya, and Leptospira, whereas mats at the base and adjacent to the dendrolitic cones were enriched in Synechococcus. They resemble the Hamelin Pool structures in that they have adventitious tufts, but differ internally in the composition and distribution of the cyanobacteria. Their internal organization seems to be just an amorphous mass of filaments. Supporting filaments, as observed in the Hamelin Pool tufts, were not recorded. 


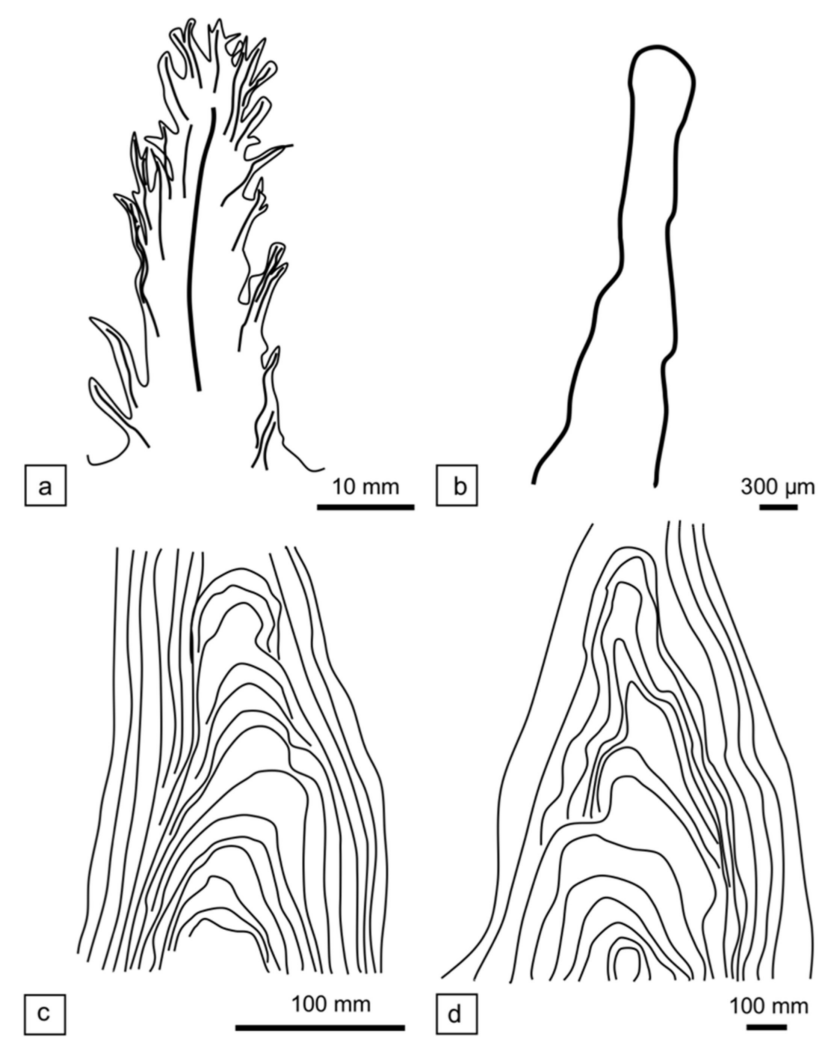

Figure 9. Comparison between tufted mat and pinnacle mat in vertical profile, $(\mathbf{a}, \mathbf{b})$ tufted mat; $(\mathbf{c}, \mathbf{d})$ pinnacle mat. (a) Tufted pillar of a Shark Bay possible dendrolitic shrub from Nilemah Embayment, Hamelin Pool, Shark Bay. (b) "Dendrolitic cone", based on vertical section illustrated in [54] Figure 3a) from Cone Pool, Little Hot Creek geothermal spring, California, USA. (c) Small conical stromatolite with an axial zone, based on vertical section illustrated in Walter et al. [20] (Figure 24), from "Conophyton Pool", Yellowstone National Park, USA. (d) A pinnacle with an axial zone from an ephemeral mat (based on an unpublished vertical section [85]) "Pamelup Pond", Lake Preston, Western Australia.

The tufted microbial mats previously described from Hamelin Pool by Flannery and Walter ([21], Figure 4c) consist predominantly of vertically-aligned bundles of filamentous cyanobacteria (tufts) that form ridges producing "centimetre-scale polygonal reticulate patterns" ([21], Figure 4a,c). The tufts were composed of "large ensheathed single filaments of Lynbya aestuarii, bundles of trichomes of Microcoleus chthonoplastes organised into single filaments, and sheathless filamentous cyanobacteria such as Oscillatoria limosa."

Flannery and Walter [21] compared their tufts to small, conical stromatolites described from hot springs in Yellowstone National Park by Walter et al. [20], and also found in other geothermal areas, such as Ohaaki Pool and Kirihoro hot pool, and in solar ponds, such as "Pamelup Pond". However, the Yellowstone and other examples of pinnacle mat are quite different in character from either type of Hamelin Pool tuft. The Flannery and Walter tufts form polygons of ridges with numerous, vertically-aligned filaments forming the axis of the ridge. Pinnacle mats are generally conical with smooth margins, are laminated, and have a distinctive axial zone. In the thin section, the laminae consist of alternating layers of vertical and horizontal filaments composed of hundreds of filamentous cyanobacteria (e.g., Phormidium), with minor quantities of other organisms $[20,81,83]$. The axial zone of the pinnacle mats is similar to that found in many conical stromatolites (such as Conophyton and Jacutophyton) throughout the geological record [84] (Figure 9c,d), which forms when unidirectional gliding filaments coil around each other to form a knot that protrudes from the substrate, providing a base for other filaments to glide upwards towards the light. Filaments remain in contact either with 
each other or the substrate, but the tips of those that reach the apex of the pinnacle form an erect cluster visible as a small tuft or nodule at the tip of the cone and gives rise to the axial zone.

Both the Flannery and Walter "tufts" contrast starkly with the Hamelin Pool shrubs. Hamelin Pool shrubs are not conical in shape, but appear as small dendritic structures dominated by a community of filamentous cyanobacteria (Figure 9) that together build the bushy, tree-like morphology (Figure 9a). They do not form extensive ridges and their internal structure and microbial composition and distribution is very different.

Lithification is a critical step in preserving a microbial structure in the rock record $[30,86]$, requiring synsedimentary calcification, which may not be entirely organically controlled $[30,87,88]$. Although the Hamelin Pool shrubs are not currently lithifying, microbial deposits have been accreting in this environment for approximately 2000 years and it is possible that in the past, shrub mats may have been preserved, thereby producing dendrolites. Alternatively, the low-to-medium preservation potential of tuft-like structures [89] may reflect the declining calcium carbonate saturation in surface seawater [7,90], hindering the ability of modern dendrolites to form. Regardless of the stage of lithification within the microbial mat, these dendrolitic structures provide insight into the effect of environmental and biotic controls on morphology. In particular, microbial mats with shrubs are a stunning example, illustrating how a varied microbial consortium operates in concert to produce a distinctive structure. Additionally, Suosaari et al. [57] have recently documented major seasonal variations in temperature, salinity, water level elevation, and probable groundwater influx, which may limit organomineralization and the subsequent lithification of shrub morphologies.

\subsection{Modularity}

Shrubs in dendrolites may represent early examples of modularity, where the community is able to generate specific morphologies to increase the overall efficiency of network activity to achieve the maximum benefits. Previous authors have noted that aggregations of filamentous cyanobacteria can influence local micro-environments, leading to complex feedbacks on morphology development [10]. This self-organization, which is achieved by the cooperative behavior of individual microbes within the community [24], suggests that microbial communities may create various morphotypes in a manner similar to multi-cellular organisms $[24,25,91]$, which may indeed be the function of shrub formation within the modern shrub-building microbial communities. The microbial ecology of bacteria working together to build varying growth forms and distinctive three-dimensional arrays conceivably displays the beginnings of a critical evolutionary pathway, where there is differentiation and division of labor [91]. With increasing scale, comes increasing complexity, from individual microbes, to shrub-building microcolonies, to laterally extensive fields of shrubs, some of them covering areas of over $100 \mathrm{~m}^{2}$. In the case of modern dendrolites, structures share many features analogous to macro-organism modules like trees and/or other woody plants, where the higher order levels of modules are the shoots, branches and leaves. When likened to a modular organism, the highly irregular morphology of the shrubs may provide insight into early functional evolutionary trends and the commonality of architectures.

Modular organisms have specific morphologies that are genetically programmed. Although it may be inappropriate to compare shrub-building microbial communities to trees, corals, sponges, etc. [25], potential microbial cooperation within the shrub suggests that these communities may behave collectively. Collective behavior within a microbial community would allow the functionality of a multicellular organism $[24,92,93]$. Microbes within a complex community can transfer meaningful information through communication to make decisions to coordinate growth, movement and biochemical activities, which allows the division of labor as well as access to the resources available to the group but not the individual, making the community an integral system [82]. As a result of the complex interactions between individual microbes, the community has more flexibility and durability, allowing improved adaptation to changing environmental conditions [24,91]. Cooperation between 
microbes at the community level may provide insight to the fossil record of dendrolites and further investigation of cross-species communication in modern microbial communities is warranted.

\section{Implications and Conclusions}

Modern analogues are critical for the understanding and interpretation of the biological habits of the ancient microbial communities preserved in the fossil record. As discussed here, there are several types of small shrub-like and pinnacle mats that have different morphologies and microbial components. A clearer concept of these interrelationships is required to determine which provide the best analogs for fossil microbialite morphology. Understanding which biological processes influence morphology can elucidate information about ancient biological communities [76]. Therefore, recognition of living shrubs in Hamelin Pool provides a living laboratory to study the community processes and interactions and provides an analog implicating the biogenicity of shrubs throughout the rock record. Varying microbial morphotypes emerge through communication and interplay between the individuals and the community that can grow and change over short time periods [24], and careful analysis of microbialite structure may even provide a basis for "microbialite morphostratigraphy" [37]. Small-scale changes in microstructure may represent a change in microbial assemblage [23] that may not be largely influenced by external environmental variables [4]. When used as a tool to correlate stratigraphic sections of the late Cambrian-early Ordovician strata of the Great Basin (western United States), microbialite morphostratigrapy has shown that two lithographic and morphostratigraphic sets are not always congruent, providing evidence against a purely environmental control on microbialite morphology [37]. In support, this study of modern shrubs in Hamelin Pool provides evidence toward a biogenic signature in morphology.

Investigations into multiple scales of shrub formation, ranging from individual microbes, to individual shrubs, to laterally extensive shrub facies belts will allow us to better understand paleoecological physiochemical environments. Furthermore, Hamelin Pool shrubs reflect the biological habit of the microbial communities that build them. Thus, morphological information preserved in the rock record may be used to infer life processes of early life on Earth, the evolution microbial community structures and the evolution of life, and may be projected to life outside this planet in the form of biosignatures [28].

Author Contributions: E.P.S. co-led field activities, including sampling, and was responsible for writing the initial draft of the manuscript. S.M.A. participated in the discussions and writing of the manuscript. R.P.R. co-led field activities and assisted in writing and editing the manuscript. J.F.S. participated in fieldwork, conducted microscopy to identify microbial mat communities, and assisted in writing and editing the manuscript. K.G. impregnated samples with wax, conducted petrographic microscopy, and assisted in writing and editing the manuscript.

Funding: This project was funded by Chevron (San Ramon, CA, USA), BP (London, UK), Repsol (Madrid, Spain), and Shell (The Hague, Netherlands). Partial support for this project was also received from NASA Exobiology and Evolutionary Biology program (NNX14AK14G).

Acknowledgments: We thank the Geological Survey of Western Australia and Hamelin Station for logistical support; the University of Miami field team for field and technical assistance; and the Western Australian Parks and Wildlife Service and the federal Department of Environment and Energy for field access and sampling permits. Hamelin Stromatolite Contribution Series \#4.

Conflicts of Interest: The authors declare that the research was conducted in the absence of any commercial or financial relationships that could be construed as a potential conflict of interest.

\section{References}

1. Knoll, A.H. The early evolution of eukaryotes-A geological perspective. Science 1992, 256, $622-627$. [CrossRef] [PubMed]

2. Burne, R.V.; Moore, L.S. Microbialites: Organosedimentary deposits of benthic microbial communities. Palaios 1997, 2, 241-254. [CrossRef]

3. Riding, R. Microbialites, stromatolites, and thrombolites. In Encyclopedia of Geobiology; Springer: Dordrecht, The Netherlands, 2011; pp. 635-654. 
4. Semikhatov, M.A.; Gebelein, C.D.; Cloud, P.; Awramik, S.M.; Benmore, W.C. Stromatolite morphogenesisProgress and problems. Can. J. Earth Sci. 1979, 16, 992-1015. [CrossRef]

5. Ginsburg, R.N. Controversies about stromatolites: Vices and virtues. In Controversies in Modern Geology; Academic Press: London, UK, 1991; pp. 25-36.

6. Awramik, S.M. The history and significance of stromatolites. In Early Organic Evolution; Schidlowski, M., Golubic, S., Kimberley, M.M., McKirdy, D.M., Trudinger, P.A., Eds.; Springer: Berlin, Germany, 1992; pp. 435-449.

7. Grotzinger, J.P.; Knoll, A.H. Stromatolites in Precambrian carbonates: Evolutionary mileposts or environmental dipsticks? Annu. Rev. Earth Planet. Sci. 1999, 27, 313-358. [CrossRef] [PubMed]

8. Brasier, M.; McLoughlin, N.; Green, O.; Wacey, D. A fresh look at the fossil evidence for early Archaean cellular life. Philos. Trans. R. Soc. B 2006, 361, 887-902. [CrossRef] [PubMed]

9. McLoughlin, N.; Wilson, L.A.; Brasier, M.D. Growth of synthetic stromatolites and wrinkle structures in the absence of microbes-implications for the early fossil record. Geobiology 2008, 6, 95-105. [CrossRef] [PubMed]

10. Shepard, R.N.; Sumner, D.Y. Undirected motility of filamentous cyanobacteria produces reticulate mats. Geobiology 2010, 8, 179-190. [CrossRef] [PubMed]

11. Bosak, T.; Knoll, A.H.; Petroff, A.P. The meaning of stromatolites. Annu. Rev. Earth Planet. Sci. 2013, 41, 21-44. [CrossRef]

12. Ibarra, Y.; Corsetti, F.A. Lateral comparative investigation of stromatolites: Astrobiological implications and assessment of scales of control. Astrobiology 2016, 16, 271-281. [CrossRef] [PubMed]

13. Andres, M.S.; Reid, R.P. Growth morphologies of modern marine stromatolites: A case study from Highborne Cay, Bahamas. Sediment. Geol. 2006, 185, 319-328. [CrossRef]

14. Awramik, S.M.; Semikhatov, M.A. The relationship between morphology, microstructure, and microbiota in three vertically intergrading stromatolites from the Gunflint Iron Formation. Can. J. Earth Sci. 1979, 16, 484-495. [CrossRef]

15. Grotzinger, J.P.; Rothman, D.H. An abiotic model for stromatolite morphogenesis. Nature 1996, 383, $423-425$. [CrossRef]

16. Kah, L.C.; Knoll, A.H. Microbenthic distribution of Proterozoic tidal flats: Environmental and taphonomic considerations. Geology 1996, 24, 79-82. [CrossRef]

17. Knoll, A.H.; Swett, K.; Burkhardt, E. Paleoenvironmental distribution of microfossils and stromatolites in the Upper Proterozoic Backlundtoppen Formation, Spitsbergen. J. Paleontol. 1989, 63, 129-145. [PubMed]

18. Turner, E.C.; James, N.P.; Narbonne, G.M. Taphonomic control on microstructure in early Neoproterozoic reefal stromatolites and thrombolites. Palaios 2000, 15, 87-111. [CrossRef]

19. McLoughlin, N.; Melezhik, V.A.; Brasier, A.T.; Medvedev, P.V. Palaeoproterozoic stromatolites from the Lomagundi-Jatuli interval of the Fennoscandian Shield. In Reading the Archive of Earth's Oxygenation: Volume 3: Global Events and the Fennoscandian Arctic Russia-Drilling Early Earth Project; Melezhik, V., Prave, A.R., Hanski, E.J., Fallick, A.E., Lepland, A., Kump, L.R., Strauss, H., Eds.; Frontiers in Earth Sciences; Springer: Berlin/Heidelberg, Germany, 2013; pp. 1298-1351.

20. Walter, M.R.; Bauld, J.; Brock, T.D. Microbiology and morphogenesis of columnar stromatolites (Conophyton, Vacerrila) from hot springs in Yellowstone National Park. In Stromatolites; Walter, M.R., Ed.; Elsevier: New York, NY, USA, 1976; pp. 273-310.

21. Flannery, D.T.; Walter, M.R. Archean tufted microbial mats and the Great Oxidation Event: New insights into an ancient problem. Aust. J. Earth Sci. 2012, 59, 1-11. [CrossRef]

22. Bartley, J.K.; Kah, L.C.; Frank, T.D.; Lyons, T.W. Deep-water microbialites of the Mesoproterozoic Dismal Lakes Group: Microbial growth, lithification, and implications for coniform stromatolites. Geobiology 2015, 13, 15-32. [CrossRef] [PubMed]

23. Golubic, S.; Hofmann, H.J. Comparison of Holocene and mid-Precambrian Entophysalidaceae (Cyanophyta) in stromatolitic algal mats: Cell division and degradation. J. Paleontol. 1976, 50, 1074-1082.

24. Ben-Jacob, E.; Levine, H. Self-engineering capabilities of bacteria. J. R. Soc. Interface 2006, 3, 197-214. [CrossRef] [PubMed]

25. Howell, J.; Woo, J.; Chough, S.K. Dendroid morphology and growth patterns: 3-D computed tomographic reconstruction. Palaeogeogr. Palaeocl. 2011, 299, 335-347. [CrossRef] 
26. Suosaari, E.P.; Reid, R.P.; Playford, P.E.; Foster, J.S.; Stolz, J.F.; Casaburi, G.; Hagan, P.D.; Chirayath, V.; Macintyre, I.G.; Planavsky, N.J.; et al. New multi-scale perspectives on the stromatolites of Shark Bay, Western Australia. Sci. Rep. 2016, 20557. [CrossRef] [PubMed]

27. Hofmann, H.J. Precambrian Remains in Canada: Fossils, Dubiofossils, and Pseudofossils. In Proceedings of the 24th International Geological Congress; International Geological Congress: Montreal, QC, Canada, 1972; pp. 20-30. Available online: https:/ / openlibrary.org/publishers/24th_International_Geological_Congress (accessed on 10 June 2018).

28. Awramik, S.M.; Grey, K. Stromatolites: Biogenicity, biosignatures, and bioconfusion. Astrobiol. Planet. Missions 2005, 5906, 59060P. [CrossRef]

29. Riding, R. (Ed.) Classification of microbial carbonates. In Calcareous Algae and Stromatolites; Springer: Berlin, Germany, 1991; pp. 21-51.

30. Riding, R. Microbial carbonates: The geological record of calcified bacterial-algal mats and biofilms. Sedimentology 2000, 47, 179-214. [CrossRef]

31. Cloud, P.E.; Semikhatov, M.A. Proterozoic stromatolite zonation. Am. J. Sci. 1969, 267, 1017-1061. [CrossRef]

32. Semikhatov, M.A. Experience in stromatolite studies in the USSR. Dev. Sediment. 1976, 20, 337-357.

33. Zhu, S. An outline of studies on the Precambrian stromatolites of China. Precambrian Res. 1982, 18, 367-396.

34. Semikhatov, M.A.; Raaben, M.E. Proterozoic stromatolite taxonomy and biostratigraphy. In Microbial Sediments; Awramik, S.M., Riding, R., Eds.; Springer: Berlin, Germany, 2000; pp. 295-306.

35. Grey, K.; Hill, A.C.; Calver, C. Biostratigraphy and stratigraphic subdivision of Cryogenian successions of Australia in a global context. Geo. Soc. Mem. 2011, 36, 113-134. [CrossRef]

36. Zaitseva, T.S.; Semikhatov, M.A.; Gorokhov, I.M.; Sergeev, V.N.; Kuznetsov, A.B.; Ivanovskaya, T.A.; Melnikov, N.N.; Konstantinova, G.V. Isotopic geochronology and biostratigraphy of Riphean deposits of the Anabar Massif, North Siberia. Stratigr. Geol. Correl. 2016, 24, 549-574. [CrossRef]

37. Shapiro, R.S.; Awramik, S.M. Microbialite morphostratigraphy as a tool for correlating Late Cambrian-Early Ordovician sequences. J. Geol. 2000, 108, 171-180. [CrossRef] [PubMed]

38. Logan, B.W.; Hoffman, P.; Gebelein, C.D. Algal mats, cryptalgal fabrics, and structures, Hamelin Pool, Western Australia. In Evolution and Diagenesis of Quaternary Carbonate Sequences, Shark Bay, Western Australia; Logan, B.W., Read, J.F., Hagan, G.M., Hoffman, P., Brown, R.G., Woods, P.J., Gebelein, C.D., Eds.; American Association of Petroleum Geologists: Tulsa, OK, USA, 1974; Volume 22, pp. 140-193.

39. Horodyski, R.J.; Bloeser, B.; Haar, S.V. Laminated algal mats from a coastal lagoon, Laguna Mormona, Baja California, Mexico. J. Sediment. Res. 1977, 47, 680-696.

40. Grey, K.; Moore, L.; Burne, R.; Pierson, B.; Bauld, J. Lake Thetis, Western Australia: An example of saline lake sedimentation dominated by benthic microbial processes. Mar. Freshw. Res. 1990, 41, 275-300. [CrossRef]

41. Ferris, F.G.; Thompson, J.B.; Beveridge, T.J. Modern freshwater microbialites from Kelly Lake, British Columbia, Canada. Palaios 1997, 12, 213-219. [CrossRef]

42. Reid, R.P.; Visscher, P.T.; Decho, A.W.; Stolz, J.F. The role of microbes in accretion, lamination and early lithification of modern marine stromatolites. Nature 2000, 406, 989-992. [CrossRef] [PubMed]

43. Gischler, E.; Gibson, M.A.; Oschmann, W. Giant holocene freshwater microbialites, Laguna Bacalar, Quintana Roo, Mexico. Sedimentology 2008, 55, 1293-1309. [CrossRef]

44. Couradeau, E.; Benzerara, K.; Moreira, D.; Gérard, E.; Kaźmierczak, J.; Tavera, R.; López-García, P. Prokaryotic and eukaryotic community structure in field and cultured microbialites from the alkaline Lake Alchichica (Mexico). PLoS ONE 2011, 6, e28767. [CrossRef] [PubMed]

45. Rowland, S.M.; Shapiro, R.S. Reef Patterns and Environmental Influences in the Cambrian and Earliest Ordovician; SEPM: Tulsa, OK, USA, 2002; Volume 72, pp. 95-128.

46. Ibarra, Y.; Corsetti, F.A.; Cheetham, M.I.; Feakins, S.J. Were fossil spring-associated carbonates near Zaca Lake, Santa Barbara, California deposited under an ambient or thermal regime? Sediment. Geol. 2014, 301, 15-25. [CrossRef]

47. Shapiro, R.S.; Rigby, J.K. First occurrence of an in situ anthaspidellid sponge in a dendrolite mound (Upper Cambrian; Great Basin, USA). J. Paleontol. 2004, 78, 645-650. [CrossRef]

48. Grey, K. (Geological Survey of Western Australia, Perth, Western Australia, Australia); Awramik, S.M. (University of Santa Barbara, Santa Barbara, California, USA); Unpublished data from Stromatolite Handbook, 2017. 
49. Cloud, P.; Wright, L.A.; Williams, E.G.; Diehl, P.; Walter, M.R. Giant stromatolites and associated vertical tubes from the Upper Proterozoic Noonday Dolomite, Death Valley region, eastern California. Geol. Soc. Am. Bull. 1974, 85, 1869-1882. [CrossRef]

50. Corsetti, F.A.; Grotzinger, J.P. Origin and significance of tube structures in Neoproterozoic post-glacial cap carbonates: Example from Noonday Dolomite, Death Valley, United States. Palaios 2005, 20, 348-362. [CrossRef]

51. Folk, R.L.; Chafetz, H.S. Pisoliths (Pisoids) in Quaternary Travertines of Tivoli, Italy. In Coated Grains; Springer: Berlin/Heidelberg, Germany, 1983; p. 474.

52. Chafetz, H.S.; Guidry, S.A. Bacterial shrubs, crystal shrubs, and ray-crystal shrubs: Bacterial vs. abiotic precipitation. Sediment. Geol. 1999, 126, 57-74. [CrossRef]

53. Gandin, A.; Capezzuoli, E. Travertine: Distinctive depositional fabrics of carbonates from thermal spring systems. Sedimentology 2014, 61, 264-290. [CrossRef]

54. Bradley, J.A.; Daille, L.K.; Trivedi, C.B.; Bojanowski, C.L.; Stamps, B.W.; Stevenson, B.S.; Nunn, H.S.; Johnson, H.A.; Loyd, S.J.; Berelson, W.M.; et al. Carbonate-rich dendrolitic cones: Insights into a modern analog for incipient microbialite formation, Little Hot Creek, Long Valley Caldera, California. NPJ Biofilms Microb. 2017, 3, 32. [CrossRef] [PubMed]

55. Playford, P.E.; Cockbain, A.E.; Berry, P.F.; Roberts, A.P.; Haines, P.W.; Brooke, B.P. The Geology of Shark Bay. Geol. Surv. Western Aust. Bull. 2013, 146, 281.

56. Logan, B.W.; Cebulski, D.E. Sedimentary environments of Shark Bay, Western Australia. In Carbonate Sedimentation and Environments, Shark Bay, Western Australia; Logan, B.W., Davies, G.R., Read, J.F., Cebulski, D.E., Eds.; American Association of Petrolium Geologists: Tulsa, OK, USA, 1970; Volume 13, pp. 1-37.

57. Suosaari, E.P.; Reid, R.P.; Abreu Araujo, T.A.; Playford, P.E.; Holley, D.K.; McNamara, J.K.; Eberli, G.P. Environmental pressures influencing living stromatolites in Hamelin Pool, Shark Bay, Western Australia. Palaios 2016, 31, 483-496. [CrossRef]

58. Burne, R.V.; Johnson, K. Sea level variation and the zonation of microbialites in Hamelin Pool, Shark Bay, Western Australia. Mar. Freshw. Res. 2012, 63, 994-1004. [CrossRef]

59. Stolz, J.F.; Reid, R.P.; Visscher, P.T.; Decho, A.W.; Norman, R.S.; Aspden, R.J.; Bowlin, E.M.; Franks, J.; Foster, J.S.; Paterson, D.M.; et al. The microbial communities of the modern marine stromatolites at Highborne Cay, Bahamas. Atoll Res. Bull. 2009, 567, 1-29. [CrossRef]

60. Franks, J.; Reid, R.P.; Aspen, R.J.; Underwood, G.J.C.; Paterson, D.M.; Prufert-Bebout, L.; Stolz, J.F. Ooid accreting diatom communities from the modern marine stromatolites at Highborne Cay, Bahamas. In Microbial Mats; Seckbach, J., Oren, A., Eds.; Springer: Berlin, Germany, 2010; pp. 277-285.

61. Stolz, J.F.; Feinstein, T.N.; Salsi, J.; Visccher, P.T.; Reid, R.P. TEM analysis of microbial mediated sedimentation and lithification in a modern marine stromatolite. Am. Min. 2001, 86, 826-833. [CrossRef]

62. Kawaguchi, T.; Decho, A.W. In-situ microspatial imaging using two-photon and confocal laser scanning microscopy of bacteria and its extracellular polymeric secretions (EPS) within marine stromatolites. Mar. BioTechnol. 2002, 4, 127-131. [CrossRef] [PubMed]

63. Paterson, D.M.; Aspden, R.J.; Visscher, P.T.; Consalvey, M.; Andres, M.S.; Decho, A.W.; Stolz, J.; Reid, R.P. Light-Dependant Biostabilisation of Sediments by Stromatolite Assemblages. PLoS Biol. 2008, 3, e3176. [CrossRef] [PubMed]

64. Golubic, S. Organisms that Build Stromatolites. Dev. Sediment. 1976, 20, 113-126.

65. Papineau, D.; Walker, J.J.; Mojzsis, S.J.; Pace, N.R. Composition and structure of microbial communities from stromatolites of Hamelin Pool in Shark Bay, Western Australia. Appl. Environ. Microbiol. 2005. [CrossRef] [PubMed]

66. Allen, M.A.; Goh, F.; Burns, B.P.; Neilan, B.A. Bacterial, archaeal and eukaryotic diversity of smooth and pustular microbial mat communities in the hypersaline lagoon of Shark Bay. Geobiology 2009, 7, 82-96. [CrossRef] [PubMed]

67. Goh, F.; Allen, M.A.; Leuko, S.; Kawaguchi, T.; Decho, A.W.; Burns, B.P.; Neilan, B.A. Determining the specific microbial populations and their spatial distribution within the stromatolite ecosystem of Shark Bay. ISME J. 2009. [CrossRef] [PubMed]

68. Ruvindy, R.; White, R.A., III; Neilan, B.A.; Burns, B.P. Unravelling core microbial metabolisms in the hypersaline microbial mats of Shark Bay using high-throughput metagenomics. ISME J. 2015. [CrossRef] [PubMed] 
69. Wong, L.H.; Smith, D.L.; Visscher, P.T.; Burns, B.P. Niche differentiation of bacterial communities at a millimeter scale in Shark Bay microbial mats. Sci. Rep. 2015. [CrossRef] [PubMed]

70. Suosaari, E.P. (Bush Heritage Australia, Hamelin Pool, Western Australia, Australia); Unpublished data for discrete $\mathrm{pH}$ water measurements across Hamelin Pool 2014-2017 (environmental monitoring), 2018.

71. Awramik, S.M.; Vanyo, J.P. Heliotropism in modern stromatolites. Science 1986, 231, 1279-1281. [CrossRef] [PubMed]

72. Castenholz, R.W.; Garcia-Pichel, F. Cyanobacterial responses to UV radiation. In Ecology of Cyanobacteria II; Springer: Dordrecht, The Netherlands, 2012; pp. 481-499.

73. Moon, Y.J.; Kim, S.I.; Chung, Y.H. Sensing and responding to UV-A in cyanobacteria. Int. J. Mol. Sci. 2012, 13, 16303-16332. [CrossRef] [PubMed]

74. Whale, G.F.; Walsby, A.E. Motility of the cyanobacterium Microcoleus chthonoplastes in mud. Br. Phycol. J. 1984, 19, 117-123. [CrossRef]

75. Petroff, A.P.; Wu, T.D.; Liang, B.; Mui, J.; Guerquin-Kern, J.L.; Vali, H.; Rothman, D.H.; Bosak, T. Reaction-diffusion model of nutrient uptake in a biofilm: Theory and experiment. J. Theor. Biol. 2011, 289, 90-95. [CrossRef] [PubMed]

76. Petroff, A.P.; Sim, M.S.; Maslov, A.; Krupenin, M.; Rothman, D.H.; Bosak, T. Biophysical basis for the geometry of conical stromatolites. Proc. Natl. Acad. Sci. USA 2010, 107, 9956-9961. [CrossRef] [PubMed]

77. Decho, A.W.; Norman, R.S.; Visscher, P.T. Quorum sensing in natural environments: Emerging views from microbial mats. Trends Microbiol. 2010, 18, 73-80. [CrossRef] [PubMed]

78. Castenholz, R.W. The behavior of Oscillatoria terebriformis in hot springs. J. Phycol. 1968, 4, 132-139. [CrossRef] [PubMed]

79. De Philippis, R.; Margheri, M.C.; Materassi, R.; Vincenzini, M. Potential of unicellular cyanobacteria from saline environments as exopolysaccharide producers. Appl. Environ. Microbiol. 1998, 64, 1130-1132. [PubMed]

80. Jones, B.; Renaut, R.W.; Rosen, M.R. Microbial biofacies in hot-spring sinters; a model based on Ohaaki Pool, North Island, New Zealand. J. Sediment. Res. 1998, 68, 413-434. [CrossRef]

81. Grey, K. (Geological Survey of Western Australia, Perth, Western Australia, Australia); Personal communication, 2017.

82. Shapiro, J.A. Thinking about bacterial populations as multicellular organisms. Annu. Rev. Microbiol. 1998, 52, 81-104. [CrossRef] [PubMed]

83. Jones, B.; Renaut, R.W.; Rosen, M.R.; Andsdell, K.M. Coniform stromatolites from geothermal systems, North Island, New Zealand. Palaios 2002, 17, 84-103. [CrossRef]

84. Hickman, A.H.; Van Kranendonk, M.J.; Grey, K. State Geoheritage Reserve R50149 (Trendall Reserve), North Pole, Pilbara Craton, Western Australia-Geology and Evidence for Early Archean Life; Record 2011/10; Geological Survey of Western Australia: Perth, Australia, 2011; 32p.

85. Grey, K. (Geological Survey of Western Australia, Perth, Western Australia, Australia); Unpublished data from Pamelup Pond: pinnacle mats, 1990.

86. Bauld, J.; D'Amelio, E.; Farmer, J.D. Modern microbial mats. In The Proterozoic Biosphere: An Interdisciplinary Study; Schopf, J.W., Klein, C., Eds.; Cambridge University Press: New York, NY, USA, 1992; pp. 261-269.

87. Krumbein, W.E.; Cohen, Y. Primary production, mat formation and lithification: Contribution of oxygenic and facultative anoxygenic cyanobacteria. In Fossil Algae; Springer: Berlin/Heidelberg, Germany, 1977; pp. 37-56.

88. Krumbein, W.E. Calcification by Bacteria and Algae. Stud. Environ. Sci. 1979, 3, 47-68.

89. Park, R.K. The preservation potential of some recent stromatolites. Sedimentology 1977, 24, 485-506. [CrossRef]

90. Grotzinger, J.P. Geochemical model for Proterozoic stromatolite decline. Am. J. Sci. 1990, 290, 80-103.

91. Andrews, J.H. Bacteria as modular organisms. Annu. Rev. Microbiol. 1998, 52, 105-126. [CrossRef] [PubMed]

92. Shapiro, J.A.; Dworkin, M. Bacteria as Multicellular Organisms; Oxford University Press: Oxford, UK, 1997.

93. Levine, H.; Ben-Jacob, E. Physical schemata underlying biological pattern formation-Examples, issues and strategies. Phys. Biol. 2004, 1, 14-22. [CrossRef] [PubMed]

(C) 2018 by the authors. Licensee MDPI, Basel, Switzerland. This article is an open access article distributed under the terms and conditions of the Creative Commons Attribution (CC BY) license (http:/ / creativecommons.org/licenses/by/4.0/). 